\title{
The Economic Value of Gas Exchange in a Paddy Field Ecosystem Using Water-Saving Irrigation
}

\author{
Yang Shihong, 2*, Xiao Yanan², Xu Junzeng, ${ }^{1,2}$ \\ ${ }^{1}$ State Key Laboratory of Hydrology - Water Resources and Hydraulic Engineering, Hohai University, \\ Nanjing, P.R. China \\ ${ }^{2}$ College of Water Conservancy and Hydropower Engineering, Hohai University, Nanjing, P.R. China
}

Received: 3 August 2017

Accepted: 26 October 2017

\begin{abstract}
The ecosystem services value of paddy fields has received increasing attention in agricultural policy decisions. This paper presents the first study to investigate the effects of rice water-saving irrigation on the economic value of gas exchange in a paddy field ecosystem based on a field experiment. The results showed that, compared to traditional flooding irrigation (FI), controlled irrigation (CI) decreased irrigation water input while maintaining high rice yield. Irrigation methods showed no significant influence on $\mathrm{O}_{2}$ production and its value in paddy fields. CI significantly reduced $\mathrm{CH}_{4}$ emissions and its negative economic value by $81.80 \%$, but increased $\mathrm{N}_{2} \mathrm{O}$ by $136.86 \%$. The economic value of $\mathrm{CO}_{2}$ uptake far outweighed the absolute value of negative economic values caused by $\mathrm{CH}_{4}$ and $\mathrm{N}_{2} \mathrm{O}$ emissions. Therefore, the irrigation methods showed no significant difference in economic value caused by greenhouse gas emissions (GHGs) from rice paddies. CI management significantly decreased ammonia volatilization (AV) and its economic value by $19.56 \%$. Overall, CI increased economic value of gas exchange $\left(\mathrm{O}_{2}\right.$ production, GHGs emission, and $\mathrm{AV}$ ) by $8.96 \%$ compared to FI paddies. Our results suggest that CI significantly increased the economic value of gas exchange in a paddy field ecosystem while drastically reducing irrigation water input and ensuring rice yields.
\end{abstract}

Keywords: water-saving irrigation, rice paddy ecosystem service, $\mathrm{O}_{2}$ emissions, GHG emissions, ammonia volatilization

\section{Introduction}

Although the main function of rice fields is to produce rice, they also provide a range of other ecosystem services [1], including $\mathrm{O}_{2}$ production, $\mathrm{CO}_{2}$ reduction, summer temperature cooling, flood mitigation, and so on [2]. Meanwhile, paddy fields have a negative effect on the environment through greenhouse gas emissions and agricultural non-point pollution [3-4]. Much literature has evaluated these ecosystem services by rice paddies, and these results show that rice fields provide more positive values in maintaining the sustainability of a regional or even global ecosystem [5-7]. Ecosystem services have been recognized throughout the rice-growing world and been considered in agricultural policy-making [8-9].

*e-mail: ysh0873@163.com 
Gas exchange is an important component of ecosystem services in rice fields [2]. In addition to carbon dioxide $\left(\mathrm{CO}_{2}\right)$ fixation and oxygen $\left(\mathrm{O}_{2}\right)$ release through rice leaf photosynthesis, a paddy field is one important source of atmospheric greenhouse gases (GHGs) [10]. The main proportion of GHGs are $\mathrm{CO}_{2}$, methane $\left(\mathrm{CH}_{4}\right)$, and nitrous oxide $\left(\mathrm{N}_{2} \mathrm{O}\right)$. In 2010, the $\mathrm{CH}_{4}$ emission of rice cultivation in China was $5.2 \mathrm{Tg}$, accounting for $22 \%$ of the total $\mathrm{CH}_{4}$ emissions of rice production in the world [11]. In addition, a rice paddy with traditional flooding irrigation management is a small source of $\mathrm{N}_{2} \mathrm{O}$ [12]. A small amount of research has analyzed the value of gas exchange in rice fields. The results conducted in Shanghai and Jiangsu Province of China showed that the total economic value of gas exchange from rice paddies was $12.99 \times 10^{3}$ and $26.15 \times 10^{3}$ RMB ha-1 [13-14]. Moreover, gas exchange values of paddy fields in 10 typical rice cultivation areas were 4.61 $\times 10^{3}-16.72 \times 10^{3}$ USD ha ${ }^{-1}$ [15]. Existing research about the economic value of gas exchange in paddy fields only considered $\mathrm{O}_{2}, \mathrm{CO}_{2}, \mathrm{CH}_{4}$, and $\mathrm{N}_{2} \mathrm{O}$. Ammonia volatilization (AV) is another important gas emission from paddy fields due to excessive nitrogen input. Sun's research showed that $\mathrm{AV}$ from urea fertilizer was a major pathway for nitrogen loss in tropical flooded rice fields, often causing losses of $50 \%$ or more of applied nitrogen fertilizer [16]. Therefore, AV should be taken into account when evaluating the value of gas exchange in paddy fields.

In addition, with increasing water scarcity and rising grain demand, water-saving irrigation techniques are being widely implemented in paddy fields [17]. The wet-dry cycles of water-saving irrigation changes the agro-ecosystem environment, including soil properties, soil water cycle, and soil nitrogen transfer and transformation and gases exchange. It is well documented that water-saving irrigation techniques such as midseason drainage, intermittent irrigation, and controlled irrigation can significantly reduce $\mathrm{CH}_{4}$ emissions but trigger substantial $\mathrm{N}_{2} \mathrm{O}$ emissions from paddy fields [12]. $\mathrm{Xu}$ et al. found that controlled irrigation reduced AV from paddy fields by $14 \%$ compared to flooding irrigation [18]. But Cui et al. found that intermittent irrigation significantly increased AV from paddy fields by $22.9 \%$ compared to flooding irrigation [19]. The changes of gases exchange caused by water-saving irrigation will affect its economic value in paddy fields. But relevant study is not available. Thus, we conducted one of the first detailed field experiments to systematically evaluate the gases exchange services of rice paddies under water-saving irrigation. The objectives of this study were to: 1) reveal the effect of water-saving irrigation on rice yield and irrigation water use efficiency; 2) investigate $\mathrm{O}_{2}$ release, GHG emissions, and $\mathrm{AV}$ of paddy fields with different irrigation management, and quantify their economic values; and 3) comprehensively analyze the economic value of gases exchange of paddy fields under water-saving irrigation.

\section{Materials and Methods}

\section{Experimental Field and Rice Cultivation}

The measurements were conducted in 2009 and 2010 during the rice growth stage at the Kunshan Irrigation and Drainage Experiment Station $\left(31^{\circ} 15^{\prime} 15^{\prime \prime} \mathrm{N}\right.$, $\left.120^{\circ} 57^{\prime} 43^{\prime \prime} \mathrm{E}\right)$ in the Taihu Lake region of China. The study area has a subtropical monsoon climate with an average annual air temperature of $15.5^{\circ} \mathrm{C}$, mean annual precipitation of $1.10 \times 10^{3} \mathrm{~mm}$, and annual evaporation of $1,365.9 \mathrm{~mm}$. The soil on the top layer is hydragric anthrosol soil, which is typical in this region. The properties of the $0-60 \mathrm{~cm}$ soil in the experimental station are described as follows: organic matter $21.9 \mathrm{~g} \mathrm{~kg}^{-1}$, total nitrogen $1.03 \mathrm{~g} \mathrm{~kg}^{-1}$, total phosphorus $1.35 \mathrm{~g} \mathrm{~kg}^{-1}$, total potassium $20.9 \mathrm{~g} \mathrm{~kg}^{-1}$, and $\mathrm{pH} 7.4$.

Two irrigation treatments - namely flooding irrigation (FI) and controlled irrigation (CI) - were designed in this field experiment. Each irrigation treatment had three replicates. The replicates were established in six plots with an area of $35 \mathrm{~m}^{2}(5 \times 7 \mathrm{~m})$ in a randomized block design. In the FI paddy fields there was a $3-5 \mathrm{~cm}$ shallow water layer after transplanting except during the midseason drainage period (inhibited ineffective tiller during the later tillering stage) and the yellow maturity stage of rice. For the CI treatment, the $5-25 \mathrm{~mm}$ shallow flooding water was maintained in the regreening stage. The irrigation was applied only to saturate the soil without flooding in other periods except during the application of fertilizers, herbicides, and pesticides with 3-5 days-worth of flooding water. The lower soil moisture thresholds for the controlled irrigation are shown in Table 1.

Table 1. Limits for controlled irrigation in different rice growth stages.

\begin{tabular}{|c|c|c|c|c|c|c|c|c|}
\hline \multirow{2}{*}{ Limit } & \multirow{2}{*}{$\begin{array}{c}\text { Regreening } \\
\text { stage }\end{array}$} & \multicolumn{3}{|c|}{ Tillering stage } & $\begin{array}{c}\text { Jointing } \\
\text { and booting } \\
\text { stage }\end{array}$ & $\begin{array}{c}\text { Heading and } \\
\text { flowering } \\
\text { stage }\end{array}$ & $\begin{array}{c}\text { Milk } \\
\text { stage }\end{array}$ & $\begin{array}{c}\text { Ripening } \\
\text { stage }\end{array}$ \\
\cline { 3 - 7 } & $25 \mathrm{~mm}$ & $100 \% \theta_{\mathrm{s} 1}$ a) & $100 \% \theta_{\mathrm{s} 1}$ & $100 \% \theta_{\mathrm{s} 1}$ & $100 \% \theta_{\mathrm{s} 2}$ & $100 \% \theta_{\mathrm{s} 3}$ & $100 \% \theta_{\mathrm{s} 3}$ & \\
\hline Upper limit & $5 \mathrm{~mm}$ & $70 \% \theta_{\mathrm{s} 1}$ & $65 \% \theta_{\mathrm{s} 1}$ & $60 \% \theta_{\mathrm{s} 1}$ & $75 \% \theta_{\mathrm{s} 2}$ & $80 \% \theta_{\mathrm{s} 3}$ & $70 \% \theta_{\mathrm{s} 3}$ & $\begin{array}{c}\text { Naturally } \\
\text { drying }\end{array}$ \\
\hline Lower limit & - & $0-20$ & $0-20$ & $0-20$ & $0-30$ & $0-40$ & $0-40$ & \\
\hline $\begin{array}{c}\text { Monitored soil } \\
\text { depth }(\mathrm{cm})\end{array}$ & - & $0-20$ & Middle & Late & & \\
\hline
\end{tabular}

$\theta_{\mathrm{s} 1}, \theta_{\mathrm{s} 2}$, and $\theta_{\mathrm{s} 3}$ represent the saturated volumetric moisture content of the soil in different rice growth stages. 
Table 2. Date and rate of nitrogen fertilization during the rice growth stage $\left(\mathrm{kg} \mathrm{N} \mathrm{ha}^{-1}\right)$.

\begin{tabular}{|c|c|c|}
\hline $\mathrm{N}$ fertilizer application & 2009 & 2010 \\
\hline $\begin{array}{l}\text { Base fertilizer } \\
\left(22 \text { June }^{\text {a) }}\right)\end{array}$ & $\begin{array}{c}56.25 \\
\left(\mathrm{CF}^{\mathrm{b})}, 22 \text { June }\right)\end{array}$ & $\begin{array}{c}48.00 \\
\text { (CF, 26 June) }\end{array}$ \\
\hline $\begin{array}{l}\text { Regreening fertilizer } \\
\qquad \text { (28 June) }\end{array}$ & $\begin{array}{c}76.95 \\
\text { (AB, 28 June) }\end{array}$ & $\begin{array}{c}64.13 \\
\text { (AB, } 1 \text { July) }\end{array}$ \\
\hline $\begin{array}{l}\text { Tillering fertilizer } \\
\text { (7 July) }\end{array}$ & $\begin{array}{c}121.80 \\
\text { (U, 7 July) }\end{array}$ & $\begin{array}{c}121.28 \\
\text { (U, 17 July) }\end{array}$ \\
\hline $\begin{array}{l}\text { Panicle fertilizer } \\
\text { (12 August) }\end{array}$ & $\begin{array}{c}69.60 \\
\text { (U, 12 August) }\end{array}$ & $\begin{array}{c}69.30 \\
\text { (U, 13 August) }\end{array}$ \\
\hline Total nitrogen & 324.6 & 302.7 \\
\hline
\end{tabular}

a) Date in the bracket is the time for the fertilizer applied.

b) $\mathrm{CF}$ is compound fertilizer $\left(\mathrm{N}, \mathrm{P}_{2} \mathrm{O}_{5}\right.$ and $\mathrm{K}_{2} \mathrm{O}$ contents are $15 \%, 15 \%$ and $15 \%$ in 2009 , and $16 \%, 12 \%$ and $17 \%$ in 2010). $\mathrm{AB}$ is ammonium bicarbonate ( $\mathrm{N}$ content is $17.1 \%$ ). $\mathrm{U}$ is urea ( $\mathrm{N}$ content is $46.2 \%$ ).

Rice variety was Japonica Rice Nanjing 46 in this experiment. Rice seedlings were transplanted with a $13.0 \times 25.0 \mathrm{~cm}$ hill spacing on 23 June and harvested on 26 October in 2009. In the 2010 experiment, rice seedlings were transplanted with the same hill spacing on 26 June and harvested on 25 October. The local farmer fertilizer practice was adopted in this experiment (Table 2). Only the basal fertilizers were incorporated into the ploughed layer, while the other fertilizers were broadcast evenly onto the soil surface.

\section{Gas Sampling}

$\mathrm{CH}_{4}$ and $\mathrm{N}_{2} \mathrm{O}$ samples were collected by the static chamber technique [20]. The chamber, consisting of two separate layers with the same size $(0.5 \times 0.5 \times 0.6 \mathrm{~m})$, was made of polyvinyl chloride. The bases for the chambers were installed in all plots before rice transplantation, and remained there until rice harvesting. Samples were collected by $60 \mathrm{~mL}$ syringes, which were connected to chambers and sealed airbags through three stopcocks. Gas samples were collected at 10:00-11:00 at an interval of 2 days for 12 days after each fertilizer application, then at an interval of 3-4 days; and a 7-day sampling interval was used during the last 2 months of rice growth. Air temperatures in the chamber were recorded simultaneously. This sampling time was based on the diurnal variation patterns of gas emission, assuming this pattern remained the same the whole season [21]. From each chamber, 4 gas samples were collected $(0,10,20$, and $30 \mathrm{~min})$. Gas samples were analyzed using a gas chromatograph (Agilent 7890A) with electron capture detectors for $\mathrm{CH}_{4}$ and $\mathrm{N}_{2} \mathrm{O}$ analyses. The $\mathrm{CH}_{4}$ and $\mathrm{N}_{2} \mathrm{O}$ fluxes were calculated according to the equation given by Zheng et al. [22],

$$
F=\rho \times h \times \frac{273}{273+T} \times \frac{d C}{d t}
$$

...where $F$ is the gas emission flux $\left(\mathrm{mg} \mathrm{m}^{-2} \mathrm{~h}^{-1}\right.$ for $\mathrm{CH}_{4}$; $\mu \mathrm{g} \mathrm{m}^{-2} \mathrm{~h}^{-1}$ for $\mathrm{N}_{2} \mathrm{O}$ ), $\rho$ is the gas density at standard state, $h$ is the height of chamber above the water surface (m), $d C / d t$ is the gas mixing ratio concentration $\left(\mathrm{mg} \mathrm{m}^{-3} \mathrm{~h}^{-1}\right.$ for $\mathrm{CH}_{4} ; \mu \mathrm{g} \mathrm{m}^{-3} \mathrm{~h}^{-1}$ for $\mathrm{N}_{2} \mathrm{O}$ ), and $T$ is the mean air temperature inside the chamber during sampling $\left({ }^{\circ} \mathrm{C}\right)$. The cumulative gas emissions during the study period were calculated by integrating cumulative gas emissions on the sampling days.

Paddy soil respiration was measured by transparent static chamber-WEST Systems portable soil flux meter (West Systems S.r.l., Italy). The sampling device consisted of three parts: a base, a transparent column, and a WEST Systems portable soil flux meter. The base and transparent column were made of polyvinyl chloride material (PVC) and transparent methyl methacrylate (organic glass), respectively. The PVC base, with diameter and height of $20 \mathrm{~cm}$ and $10 \mathrm{~cm}$, was embedded $5 \mathrm{~cm}$ into the paddy soil (without rice) before rice transplantation, and remained there until rice harvesting. The transparent column was divided into two separate layers (with diameter of $20 \mathrm{~cm}$ and height of $20 \mathrm{~cm}$ or $40 \mathrm{~cm}$ ) for different height of rice. The WEST Systems flux meter was a portable instrument for measuring soil gas flux based on the accumulation chamber method. It consisted of an air chamber (with diameter and height of $20 \mathrm{~cm}$ and $10 \mathrm{~cm}$ ) and a host (an LI840 analyzer meter). A sealed water channel was used to join the base, transparent column and WEST Systems portable soil flux meter. Paddy soil respiration was measured at 10:00-11:00 at an interval of 7-10 days from transplanting to harvest. As $\mathrm{CH}_{4}$ and $\mathrm{N}_{2} \mathrm{O}$, soil respiration rate at this sampling time were considered to be daily means. The output result from the system was the variation rate of the $\mathrm{CO}_{2}$ concentration in the chamber. And the paddy soil respiration can be calculated as Equations (2) and (3):

$$
\begin{gathered}
F=K \times S \\
K=\frac{86400 \times P}{10^{6} \times R \times T_{k}} \times \frac{V}{A}
\end{gathered}
$$

...where $K$ is the accumulation chamber factor in mol s ppm-1 $\mathrm{m}^{-2} \mathrm{~d}^{-1}, \mathrm{~S}$ is the variation rate of the $\mathrm{CO}_{2}$ concentration in $\mathrm{ppm} \mathrm{s} \mathrm{s}^{-1}, F$ is the flux of $\mathrm{CO}_{2}$ in $\mathrm{mol} \cdot \mathrm{m}^{-2} \cdot \mathrm{d}^{-1}, P$ represents the barometric pressure expressed in mBar, $R$ is the gas constant $(0.0831451 \mathrm{bar}$ $\left.\mathrm{L} \mathrm{K}^{-1} \mathrm{~mol}^{-1}\right), T_{k}$ represents the air temperature expressed in kelvin, $V$ is the chamber net volume in cubic meters, and $A$ represents the chamber inlet net area in square meters. Cumulative $\mathrm{CO}_{2}$ emission through soil respiration for the rice growth stage was calculated by integrating cumulative soil respiration rates on the sampling days.

The vented method, which is simpler in structure, easier to operate, and higher in precision and accuracy [23], was used to monitor ammonia $\left(\mathrm{NH}_{3}\right)$ volatilization from the paddy fields in this study. The vented 
chamber consisted of a PVC collector (20 cm high) and a phosphoglycerol-soaked sponge to absorb ammonia. The sponges were collected and replaced daily after $\mathrm{N}$ fertilizer application for one week, collected at 2-3 days of interval for another week, and then at one-week intervals. Then sponges were immersed in $300 \mathrm{ml}$ of 1.0 M KCL solution in $500 \mathrm{ml}$ containers and shaken on a reciprocating shaker before the extract solutions were analyzed by an ultraviolet-visible spectrophotometer (UNICO 2800) followed by Nessler's reagent colorimetric method [24]. And $\mathrm{NH}_{3}$ volatilization rate was calculated according to Eq. (4):

$$
R_{A V}=\frac{M}{A \times D} \times 10^{-2}
$$

...where $R_{A V}$ is the $\mathrm{NH}_{3}$ volatilization rate in $\mathrm{kg}$ $\mathrm{N} \mathrm{hm}{ }^{-2} \mathrm{~d}^{-1}, M$ is the $\mathrm{NH}_{3}-\mathrm{N}$ collected by the PVC collector in $\mathrm{mg}, A$ is the cross sectional area of the PVC collector in $\mathrm{m}^{2}$, and $D$ is the interval for $\mathrm{NH}_{3}$ volatilization samples collection in $d$. Cumulative $\mathrm{NH}_{3}$ volatilization was calculated as the sum of daily volatilization over the given period.

Irrigation was conducted according to soil moisture and water layer of paddy fields. Soil moisture or pond water depths were measured every day by a time domain reflectometer (TDR, Soil Moisture Equipment Limited Corporation of America) and vertical rulers, respectively. Irrigation water volumes were measured by a water meter installed on the pipes of every plot. Yield was determined for each plot after rice was harvested. Rice dry matter amount (included root) of every plot was measured at the ripening stage. The rice plants were dried at $105^{\circ} \mathrm{C}$ for $30 \mathrm{~min}$ for deactivation of enzymes, and then dried at $80^{\circ} \mathrm{C}$ to constant weight. The constant weight was the rice dry matter amount.

\section{Estimating the Economic Value of Gases Exchange}

According to the formula of photosynthesis, $\mathrm{O}_{2}$ emission can be estimated by the rice dry matter amount. While producing $162 \mathrm{~g}$ dry matter, a paddy field can supply $193 \mathrm{~g}$ oxygen. Then the economic value of $\mathrm{O}_{2}$ emissions from paddy fields was calculated using the rice dry matter amount and the price of medical $\mathrm{O}_{2}$ in China:

$$
V_{O_{2}}=C_{a} \times \alpha \times M_{d}
$$

...where $\mathrm{V}_{2}$ is the economic value of $\mathrm{O}_{2}$ emissions $\left(\mathrm{RMB} \mathrm{ha}{ }^{-1}\right), C_{a}$ is the price of medical $\mathrm{O}_{2}$ in China (0.4 RMB kg-1, [25]), $\alpha$ is the coefficient of conversion from rice dry matter amount to $\mathrm{O}_{2}$ emission (1.19), and is the rice dry matter amount $\left(\mathrm{kg} \mathrm{ha}^{-1}\right)$.

The $\mathrm{CH}_{4}$ and $\mathrm{N}_{2} \mathrm{O}$ emissions from paddy fields can be converted to $\mathrm{CO}_{2}$ equivalents through global warming potential (GWP). GWP is an index defined as the cumulative radiative forcing between the present and some chosen later time "horizon" caused by a unit mass of gas emitted now ( $\mathrm{CO}_{2}$ is the reference gas). On a 100 -year time horizon, the GWP for $\mathrm{CH}_{4}$ is 34, whereas that for $\mathrm{N}_{2} \mathrm{O}$ is 298, when GWP value for $\mathrm{CO}_{2}$ is taken as 1 [26]. Thus, the emissions of $\mathrm{CH}_{4}$ and $\mathrm{N}_{2} \mathrm{O}$ from paddy fields can be converted to $\mathrm{CO}_{2}$ equivalents, which can further be converted to pure $\mathrm{C}$ emissions using the following equation:

$$
M_{C}=0.2729\left(M_{C_{2}}+34 M_{C_{4}}+298 M_{N_{2} O}\right)
$$

...where $M_{C}$ is the emission of $\mathrm{CO}_{2}, \mathrm{CH}_{4}$, and $\mathrm{N}_{2} \mathrm{O}$ in pure C from paddy field $\left(\mathrm{kg} \mathrm{ha}^{-1}\right), \mathrm{MCO}_{2}, \mathrm{MCH}_{4}$, and $\mathrm{MNO}_{2}$ are the emissions of $\mathrm{CO}_{2}, \mathrm{CH}_{4}$, and $\mathrm{N}_{2} \mathrm{O}$ from paddy field, respectively $\left(\mathrm{kg} \mathrm{ha} \mathrm{h}^{-1}\right) . \mathrm{CO}_{2}$ emissions of paddy field ecosystem is the difference between $\mathrm{CO}_{2}$ fixed by rice photosynthesis and the $\mathrm{CO}_{2}$ released by paddy soil respiration.

$$
M_{\mathrm{CO}_{2}}=\beta \times M_{d}
$$

...where $\beta$ is the coefficient of conversion from rice dry matter amount to $\mathrm{CO}_{2}$ emission (1.63).

The economic value of greenhouse gases (GHGs) emission can be estimated by the Swedish carbon tax [27]:

$$
V_{C}=C_{b} \times M_{C}
$$

...where $V_{C}$ is the economic value associated with GHGs emission (RMB hat), $C_{b}$ is the Swedish carbon tax (0.15 USD kg-1 C, 1.02 and $1.01 \mathrm{RMB} \mathrm{kg}^{-1}$ $\mathrm{C}$ according to the exchange rate between $\mathrm{RMB}$ and USD in 2009 and 2010).

The economic value of ammonia volatilization (AV) from a paddy field can be estimated according to following equation:

$$
V_{\mathrm{NH}_{3}}=\mathrm{C}_{c} \times \mathrm{M}_{\mathrm{NH}_{3}}
$$

...where $V_{\mathrm{NH}_{3}}$ is the economic value of $\mathrm{AV}$ $\left(\mathrm{RMB} \mathrm{ha}{ }^{-1}\right), C_{C}$ is the marginal reduction cost of AV (79.15 $\mathrm{RMB} \mathrm{kg}^{-1} \mathrm{~N}$ according to the marginal reduction cost method, [28]), and $M_{N_{3}}$ is the volatilization of $\mathrm{NH}_{3}$ from a paddy field, respectively $\left(\mathrm{kg} \mathrm{N} \mathrm{ha}^{-1}\right)$.

Then the economic value of gases exchange of paddy fields $\left(V_{G}\right)$ is the sum of $V_{O_{2}}, V_{C}$, and $V_{\mathrm{NH}_{3}}$ :

$$
V_{G}=V_{O_{2}}+V_{C}+V_{N_{3}}
$$

\section{Statistical Analysis}

Statistical analysis was carried out following standard procedures on a randomized plot design (SPSS 17.0). Significant comparisons were calculated based on F-tests and least significant difference (LSD) tests. 
Table 3. Rice yield and irrigation water use efficiency.

\begin{tabular}{|c|c|c|c|c|}
\hline \multicolumn{2}{|c|}{ Treatment } & $\begin{array}{c}\text { Yield } \\
\left(10^{3} \mathrm{~kg} \mathrm{ha}^{-1}\right)\end{array}$ & $\begin{array}{c}\text { Irrigation } \\
\text { water volume } \\
(\mathrm{mm})\end{array}$ & $\begin{array}{c}\text { IWUE } \\
\left(\mathrm{kg} \mathrm{m}^{-3}\right)\end{array}$ \\
\hline \multirow{2}{*}{2009} & FI & $10.3 \mathrm{a}$ & $635.95 \mathrm{~b}$ & $1.63 \mathrm{~b}$ \\
\cline { 2 - 5 } & CI & $9.89 \mathrm{a}$ & $233.30 \mathrm{a}$ & $4.24 \mathrm{a}$ \\
\hline \multirow{2}{*}{2010} & FI & $9.26 \mathrm{a}$ & $645.00 \mathrm{~b}$ & $1.44 \mathrm{~b}$ \\
\cline { 2 - 5 } & CI & $9.36 \mathrm{a}$ & $263.00 \mathrm{a}$ & $3.56 \mathrm{a}$ \\
\hline
\end{tabular}

Means in the same column in 2009 or 2010 followed by the same letter are not significantly different $(p<0.05)$.

\section{Results and Discussion}

\section{Rice Yield and Irrigation Water Use Efficiency}

Compared to FI, rice yields in CI treatment were reduced by $4.32 \%$ in 2009 and increased by $1.04 \%$ in 2010 (Table 3). But irrigation methods showed no significant difference on rice yield. However, irrigation water volume was dramatically reduced by $63.31 \%$ and $59.22 \%$ in 2009 and 2010 owing to the application of water-saving irrigation techniques. The maintenance of high rice yields and the significant reduction of irrigation water volume obviously improved the irrigation water use efficiency in the CI treatment. Irrigation water use efficiency of the CI treatment in 2009 and 2010 were 2.60 and 2.47 times higher than those of FI.

\section{$\mathrm{O}_{2}$ Emission and its Economic Value}

Rice dry matter, calculated $\mathrm{O}_{2}$ emissions, and their economic values with different irrigation methods are shown in Table 4. Water-saving irrigation increased rice dry matter compared to flooding irrigation, which was consistent with similar studies of different rice watersaving irrigation [29-30]. Seasonal $\mathrm{O}_{2}$ emissions and their economic values calculated through dry matter amount also showed the same results as dry matter amount between different irrigation methods. The average $\mathrm{O}_{2}$ emission and its value of CI paddy fields was $26.92 \times 10^{3} \mathrm{~kg} \mathrm{ha}^{-1}$ and $10.77 \times 10^{3} \mathrm{RMB} \mathrm{ha}^{-1}$, both increased by $2.08 \%$ compared to FI paddy field. But the results of ANOVA showed that rice dry matter amounts,

Table 4. Rice dry matter, $\mathrm{O}_{2}$ emissions, and economic value.

\begin{tabular}{|c|c|c|c|c|}
\hline \multicolumn{2}{|c|}{ Treatment } & $\begin{array}{c}\text { Dry matter } \\
\left(10^{3} \mathrm{~kg} \mathrm{ha}^{-1}\right)\end{array}$ & $\begin{array}{c}\mathrm{O}_{2} \text { emission } \\
\left(10^{3} \mathrm{~kg} \mathrm{ha}^{-1}\right)\end{array}$ & $\begin{array}{c}\text { Value of } \mathrm{O}_{2} \\
\text { emission } \\
\left(10^{3} \mathrm{RMB} \mathrm{ha}^{-1}\right)\end{array}$ \\
\hline \multirow{2}{*}{2009} & FI & $22.64 \mathrm{a}$ & $26.94 \mathrm{a}$ & $10.78 \mathrm{a}$ \\
\cline { 2 - 5 } & CI & $23.12 \mathrm{a}$ & $27.52 \mathrm{a}$ & $11.01 \mathrm{a}$ \\
\hline \multirow{2}{*}{2010} & FI & $21.68 \mathrm{a}$ & $25.80 \mathrm{a}$ & $10.32 \mathrm{a}$ \\
\cline { 2 - 5 } & CI & $22.12 \mathrm{a}$ & $26.32 \mathrm{a}$ & $10.53 \mathrm{a}$ \\
\hline
\end{tabular}

Means in the same column in 2009 or 2010 followed by the same letter are not significantly different $(p<0.05)$.
$\mathrm{O}_{2}$ emissions, and their economic values under different irrigation management had no significant difference. These values of $\mathrm{O}_{2}$ emissions were similar to those for the paddy field ecosystems in suburban Shanghai, also located in the Taihu Lake region of China (9549 to $12277 \mathrm{RMB} \mathrm{ha}^{-1}$, [13]).

\section{GHG Regulation and its Economic Values}

During the rice growth stage, a paddy field is as sink for $\mathrm{CO}_{2}$, although the strength of the sink varies according to different irrigation modes (Table 5). The ANOVA results showed the $\mathrm{CO}_{2}$ uptake in two irrigation managements showed no significant difference. $\mathrm{CH}_{4}$ and $\mathrm{N}_{2} \mathrm{O}$ emissions from paddy fields had an obvious tradeoff relationship. The $\mathrm{CH}_{4}$ emissions from the CI paddy field were significantly less than those from the FI paddy field $(p<0.05)$, on average by $81.80 \%$. However, the $\mathrm{N}_{2} \mathrm{O}$ emissions from the CI paddy field were significantly greater than those from the FI treatment $(p<0.05)$, on average by $136.86 \%$. These results were due to $\mathrm{CH}_{4}$ and $\mathrm{N}_{2} \mathrm{O}$ formation in soils requiring contrasting soil redox potential (Eh) conditions. As a result, Yu and Patrick showed that ideal Eh values favoring $\mathrm{N}_{2} \mathrm{O}$ formation $\left(\mathrm{Eh}>180 \mathrm{mV}\right.$ ) restricted $\mathrm{CH}_{4}$ formation (which peaks at $\mathrm{Eh}=-150 \mathrm{mV}$ ) [31]. The non-ponding water management of a $\mathrm{CI}$ paddy field was the reason for mitigating $\mathrm{CH}_{4}$ emissions and triggering substantial $\mathrm{N}_{2} \mathrm{O}$ emissions in this study. Literature about the effect of other rice water-saving irrigation modes as intermittent irrigation, flooding-midseason drainage-frequent water logging with intermittent irrigation (FDF), and floodingmidseason drainage-reflooding-moist intermittent irrigation without water logging (FDFM) on $\mathrm{CH}_{4}$ and $\mathrm{N}_{2} \mathrm{O}$ emissions had been well documented [3234]. In relation to continuous flooding irrigation, the intermittent irrigation reduced seasonal $\mathrm{CH}_{4}$ emissions by $47 \%$, and increased $\mathrm{N}_{2} \mathrm{O}$ emissions by $876 \%$ in the Brazil paddy fields [35]. Midseason drainage significantly reduced seasonal $\mathrm{CH}_{4}$ fluxes of paddy fields in South Korea by $50-53 \%$, but significantly increased $\mathrm{N}_{2} \mathrm{O}$ flux by $20-37 \%$ over conventional flooding [36]. Irrigation techniques had no significant effect on GHG regulation due to the main part of GHGs in this study being to uptake $\mathrm{CO}_{2}$.

Table 5. Seasonal $\mathrm{CH}_{4}, \mathrm{~N}_{2} \mathrm{O}$ emissions, and uptake of $\mathrm{CO}_{2}$.

\begin{tabular}{|c|c|c|c|c|c|}
\hline \multicolumn{2}{|c|}{ Treatment } & $\begin{array}{c}\mathrm{CO}_{2} \text { uptake } \\
\left(10^{3} \mathrm{~kg}\right. \\
\left.\mathrm{CO}_{2} \mathrm{ha}^{-1}\right)\end{array}$ & $\begin{array}{c}\mathrm{CH}_{4} \\
\text { emission } \\
\left(\mathrm{kg} \mathrm{CH}_{4}\right. \\
\left.\mathrm{ha}^{-1}\right)\end{array}$ & $\begin{array}{c}\mathrm{N}_{2} \mathrm{O} \\
\text { emission } \\
\left(\mathrm{kg} \mathrm{N}_{2} \mathrm{O}\right. \\
\left.\mathrm{ha}^{-1}\right)\end{array}$ & $\begin{array}{c}\text { GHGs } \\
\text { regulation } \\
\left(10^{3} \mathrm{~kg}\right. \\
\left.\mathrm{CO}_{2} \mathrm{ha}^{-1}\right)\end{array}$ \\
\hline \multirow{2}{*}{2009} & FI & $31.68 \mathrm{a}$ & $72.06 \mathrm{a}$ & $1.57 \mathrm{~b}$ & $28.76 \mathrm{a}$ \\
\cline { 2 - 7 } & CI & $29.99 \mathrm{a}$ & $13.52 \mathrm{~b}$ & $3.83 \mathrm{a}$ & $28.39 \mathrm{a}$ \\
\hline \multirow{2}{*}{2010} & FI & $30.28 \mathrm{a}$ & $66.23 \mathrm{a}$ & $2.32 \mathrm{~b}$ & $27.34 \mathrm{a}$ \\
\cline { 2 - 7 } & CI & $28.60 \mathrm{a}$ & $11.68 \mathrm{~b}$ & $5.32 \mathrm{a}$ & $26.62 \mathrm{a}$ \\
\hline
\end{tabular}

Means in the same column in 2009 or 2010 followed by the same letter are not significantly different $(p<0.05)$. 
Table 6. Economical values of GHGs regulation (RMB ha-1).

\begin{tabular}{|c|c|c|c|c|c|}
\hline \multicolumn{2}{|c|}{ Treatment } & $\begin{array}{c}\mathrm{CO}_{2} \text { up- } \\
\text { take }\end{array}$ & $\begin{array}{c}\mathrm{CH}_{4} \\
\text { emission }\end{array}$ & $\begin{array}{c}\mathrm{N}_{2} \mathrm{O} \\
\text { emission }\end{array}$ & $\begin{array}{c}\text { GHGs } \\
\text { regulation }\end{array}$ \\
\hline \multirow{2}{*}{2009} & FI & $8,852.31 \mathrm{a}$ & $-684.59 \mathrm{a}$ & $-130.41 \mathrm{~b}$ & $8,037.31 \mathrm{a}$ \\
\cline { 2 - 6 } & CI & $8,380.90 \mathrm{a}$ & $-128.44 \mathrm{~b}$ & $-318.62 \mathrm{a}$ & $7,933.85 \mathrm{a}$ \\
\hline \multirow{2}{*}{2010} & FI & $8,384.49 \mathrm{a}$ & $-623.58 \mathrm{a}$ & $-191.53 \mathrm{~b}$ & $7,569.38 \mathrm{a}$ \\
\cline { 2 - 6 } & CI & $7,919.55 \mathrm{a}$ & $-109.96 \mathrm{~b}$ & $-439.36 \mathrm{a}$ & $7,370.23 \mathrm{a}$ \\
\hline
\end{tabular}

Means in the same column in 2009 or 2010 followed by the same letter are not significantly different $(p<0.05)$.

Compared to FI treatment, CI management significantly reduced the negative economic value of $\mathrm{CH}_{4}$ emissions on average by $81.80 \%$ from paddy fields, but significantly increased the negative economic value of $\mathrm{N}_{2} \mathrm{O}$ emission on average by $136.86 \%$ (Table 6). The economic value of $\mathrm{CO}_{2}$ uptake far outweighed the absolute value of negative economic values caused by $\mathrm{CH}_{4}$ and $\mathrm{N}_{2} \mathrm{O}$ emissions. Therefore, the economic values of GHGs regulation by rice paddies were all positive for both irrigation treatments. Moreover, ANOVA analysis showed that the differences among economic values of $\mathrm{CO}_{2}$ uptake and GHGs regulation were not statistically significant. Average economic values of GHG regulations for FI and CI paddy fields were 7,803.35 and 7,652.04 RMB ha' ${ }^{-1}$.

\section{Ammonia Volatilization and its Economic Value}

Seasonal AV of CI treatment was 58.35 and $54.16 \mathrm{~kg} \mathrm{~N} \mathrm{ha}{ }^{-1}$, reduced by $18.57 \%$ and $20.55 \%$ compared to FI in 2009 and 2010 (Fig. 1). Due to the reduction of seasonal $\mathrm{AV}, \mathrm{CI}$ management significantly decreased economic value of $\mathrm{AV} \quad(p<0.05)$. The economic value of $\mathrm{AV}$ from $\mathrm{CI}$ treatment was 4,618.20 and 4,286.65 RMB ha ${ }^{-1}$ in 2009 and 2010, with an average reduction of $19.56 \%$ compared to FI. AV



Fig. 1. AV from paddy fields and its economic values. dominated the main part of nitrogen loss from paddy fields. Existing research shows that nitrogen loss through $\mathrm{AV}$ was about $10-60 \%$ of $\mathrm{N}$ application in a paddy field [37]. A large amount of AV would cause serious environmental problems as acidification, eutrophication of surface water [38], and changes in biodiversity. In this study, nitrogen loss caused by AV accounted for $17.89-22.52 \%$ of nitrogen fertilizer input. Much literature has addressed the variation, influencing factors, regulation measures, and so on of $\mathrm{AV}$ from paddy fields. But there has been no relevant research about the negative economic value of AV from paddy fields. The negative of economic value of $\mathrm{AV}$ from paddy fields under traditional flooding irrigation and water-saving irrigation were studied in this research.

\section{Total Economic Values of Gas Exchange}

Fig. 2 shows the economic values of gas exchange from paddy fields under different irrigation management. The economic values of gas exchange for CI paddy fields were $14.32 \times 10^{3}$ and $13.61 \times 10^{3}$ RMB ha ${ }^{-1}$ in 2009 and 2010. For FI treatment, these values were $13.14 \times 10^{3}$ and $12.49 \times 10^{3} \mathrm{RMB} \mathrm{ha}^{-1}$ in 2009 and 2010. Water-saving irrigation management had greater economic value of gas exchange of paddy fields, with an increase on average by $8.96 \%$ compared to traditional flooding irrigation while maintaining high rice yield and significantly decreasing irrigation water input.

There is a growing recognition through the ricegrowing world that a better understanding of the ecosystem services of the rice environment is needed [9]. But relevant data are not available in many countries due to the challenge of some methodologies to measure and estimate the ecosystem service of paddy fields. This has led to the neglect and underestimation of rice paddies' ecosystem service in the process of agricultural policy-making. In china, large areas of paddy fields have been converted into urban and industrial lands with the acceleration of the urbanization process.

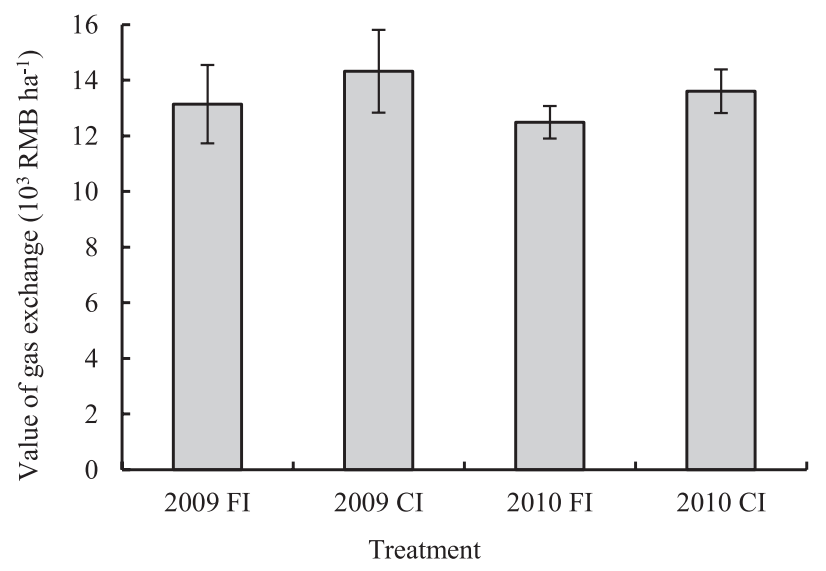

Fig. 2. Economic values of gas exchange of paddy fields. 
Liu et al. found that the rice cultivation area of China showed a decreasing trend during 1980-2010, reduced from 33.87 million ha in 1980 to 29.87 million ha in 2010, and the lowest point appeared in 2003 (26.53 million ha) [39]. For China, which has a population of 1.38 billion [40], food security is an important basis for economic development, social stability, and national security [41]. In order to achieve sustainable development, conservation of existing rice paddies is one of the most important issues faced by the Chinese government for assuring food security [13]. Therefore, a comprehensive evaluation of rice field ecosystem is urgent. It enables people to realize the importance of rice fields, and also provides a scientific basis for setting agricultural policies.

Water scarcity is one reason for the decrease of rice planting area in China. With increasing water scarcity and rising grain demand, water-saving irrigation techniques are being widely implemented in paddy fields [17]. Rice water-saving irrigation can significantly reduce irrigation water input and maintain high rice yield. But its environmental effect has also aroused wide concern. As it can mitigate the greenhouse effect of methane and nitrous oxide emissions [33-34] and reduce nitrogen and phosphorus losses through runoff and leaching [3]. Water-saving irrigation affects not only the ability of rice fields to produce food but also the environment and the ecosystem service of rice fields. But relevant research about the effect of irrigation techniques on ecosystem service of paddy fields is not available. In this study, the value of gas exchange as a service in rice paddies under different irrigation modes was estimated. The results showed that watersaving irrigation management increased the economic value of gas exchange of paddy fields on average by $8.96 \%\left(1.15 \times 10^{3} \mathrm{RMB} \mathrm{ha} \mathrm{h}^{-1}\right)$ compared to traditional flooding irrigation while maintaining high rice yield and significantly decreasing irrigation water input. The study area located in Taihu Lake region, in which approximately $75 \%$ (1.24 million ha) of arable land is used for rice growth. In the event of a comprehensive promotion of rice water-saving irrigation in the Taihu Lake region, the irrigation input of rice cultivation will be decreased by 4.85 billion $\mathrm{m}^{3}$, and economic value of gas exchange of paddy fields will be increased by 1.42 billion RMB compared to traditional flooding irrigation according to the results of this study. The estimation showed that rice water-saving irrigation technique plays an important role in conserving and enhancing the economic value of gas exchange for rice paddies. In addition to gas exchange, rice paddies have some other ecosystem services, as primary production, soil organic matter accumulation, water regulation, and flood control and so on. Hence, further research about comprehensive evaluation of economic values of rice paddies under different irrigation modes is needed. This will contribute to widespread use of rice water-saving irrigation technologies and sustainable utilization of water and soil resources in paddy fields.

\section{Conclusions}

This is the first study to investigate the effects of rice water-saving irrigation on the economic value of gas exchange in a paddy field ecosystem. Three kinds of gas regulation services, the production of $\mathrm{O}_{2}$, the regulation of GHGs, and the AV in rice paddy ecosystem were clearly affected by the irrigation method of rice. Compared to FI, CI led to a reduction by more than half of irrigation water input while maintaining high rice yield. The average $\mathrm{O}_{2}$ emissions and its value of CI treatment were increased compared to FI, but the differences were not significant. A notable tradeoff relationship between $\mathrm{CH}_{4}$ and $\mathrm{N}_{2} \mathrm{O}$ emissions was observed in the rice paddy ecosystem under both $\mathrm{CI}$ and FI. Compared to FI treatment, CI significantly reduced $\mathrm{CH}_{4}$ emissions and its negative economic value on average, but significantly increased $\mathrm{N}_{2} \mathrm{O}$ emissions and its negative economic value. $\mathrm{CO}_{2}$ uptake of two irrigation management systems shows no significant difference. And the economic value of $\mathrm{CO}_{2}$ uptake far outweighed the absolute value of negative economic values caused by $\mathrm{CH}_{4}$ and $\mathrm{N}_{2} \mathrm{O}$ emissions. Therefore, the economic values of GHG regulation by rice paddies were all positive for both irrigation treatments, and there was no significant difference. CI management triggered a significant decrease of $\mathrm{AV}$ and its economic value. Overall, water-saving irrigation management had greater economic value of gas exchange of paddy fields, increased on average by $8.96 \%$ compared to traditional flooding irrigation. According to the results of this study, 4.85 billion $\mathrm{m}^{3}$ of irrigation water will be saved and 1.42 billion RMB of ecosystem service value provided by gas exchange in paddy field will be increased in the event of a comprehensive promotion of rice water-saving irrigation in the Taihu Lake region. Our results suggest that CI significantly increased the economic value of gas exchange in the paddy field ecosystem while drastically reducing irrigation water input and ensuring crop yields.

\section{Acknowledgements}

This research was financially supported by the National Natural Science Foundation of China (No. 51579070), the Fundamental Research Funds for Central Universities (Nos. 2014B17114 and 2015B34514), the Advanced Science and Technology Innovation Team in Colleges and Universities in Jiangsu Province, and A Project Funded by the Priority Academic Program Development of Jiangsu Higher Education Institutions.

\section{References}

1. BOUMAN B.A.M., HUMPHREYS E., TUONG T.P., BARKER R. Rice and water. Advances in Agronomy, 92, 187, 2007. 
2. ZHANG B., LI,W.H., XIE G.D. Ecosystem services research in China: Progress and perspective. Ecological Economics, 69 (7), 1389, 2010.

3. YANG S.H., PENG S.Z., XU J.Z., HE Y.P., WANG Y.J. Effects of water saving irrigation and controlled release nitrogen fertilizer managements on nitrogen losses from paddy fields. Paddy Water Environment, 13 (1), 71, 2015.

4. CARLSON KM., GERBER JS., MUELLER ND., HERRERO M., MACDONALD GK., BRAUMAN KA., HAVLIK P., O'CONNELL CS., JOHNSON JA., SAATCHI S., WEST PC. Greenhouse gas emissions intensity of global croplands. Nature Climate Change, 7 (1), 63, 2017.

5. YOSHIKAWA N., NAGAO N., MISAWA S. Evaluation of the flood mitigation effect of a paddy field dam project. Agricultural Water Management, 97 (2), 259, 2010.

6. NATUHARA Y. Ecosystem services by paddy fields as substitutes of natural wetlands in Japan. Ecological Engineering, 56 (SI), 97, 2013.

7. FANG F.P., FENG J.F., LI F.B., PENG S.B. Impacts of the north migration of China's rice production on its ecosystem service value during the last three decades (1980-2014). Journal of Integrative Agriculture, 16 (1), 76, 2017.

8. LIU C.W., ZHANG S.W., YAO H.P., LIN K.H., LIN W.T. Appraisal of affordable green subsidy of rice paddy in Taiwan. Paddy and Water Environment, 8 (3), 207, 2010.

9. XIE G.D., XIAO Y. Review of Agro-ecosystem services and their values. Chinese Journal of Eco-Agriculture, 21 (6), 645, 2013.

10. CAI Z.C. Greenhouse gas budget for terrestrial ecosystems in China. Science China-Earth Sciences, 55 (2), 173, 2012)

11. FAOSTAT. http://faostat.fao.org. 2012.

12. HOU H.J., PENG S.Z., XU J.Z., YANG S.H., MAO Z. Seasonal variations of $\mathrm{CH}_{4}$ and $\mathrm{N}_{2} \mathrm{O}$ emissions in response to water management of paddy fields located in Southeast China. Chemosphere, 89 (7), 884, 2012.

13. XIAO Y., XIE G.D., LU C.X., DING X.Z., LU Y. The value of gas exchange as a service by rice paddies in suburban Shanghai, PR China. Agriculture, Ecosystems and Environment, 109 (3-4), 273, 2005.

14. XU Q., YANG L.Z., DONG Y.H., XU H., YAN T.M., WANG D.J., LI Y.D., ZHANG J.B., ZHAO C.J., ZHAI Y.S., LU Y.M., CAI Z.C. Rice field ecosystem in China. Chinese Agricultural Press, Beijing, China. 1998

15. XIAO Y., AN K., XIE G., LU C. Evaluation of ecosystem services provided by 10 typical rice paddies in China. Journal of Resources and Ecology, 2 (4), 328, 2011.

16. SUN H.J., ZHANG H.L., POWLSON D., MIN J., SHI W.M. Rice production, nitrous oxide emission and ammonia volatilization as impacted by the nitrification inhibitor 2-chloro-(trichloromethyl)-pyridine. Field Crop Research, 173, 1, 2015.

17. MAO Z. Water saving irrigation for rice and its effect on environment. Engineering Science, 4 (7), 8, 2002.

18. XU J.Z., PENG S.Z., YANG S.H., WANG W.G. Ammonia volatilization losses from a rice paddy with different irrigation and nitrogen managements. Agricultural Water Management, 104, 184, 2012.

19. CUI Y.L., LI Y.H., LV G.A., SHA Z.R. Nitrogen movement and transformation with different water supply for paddy rice. Advances in Water Science, 15 (3), 280, 2004.

20. YANG S.H., PENG S.Z., XU J.Z., LUO Y.F., LI D.X. Methane and nitrous oxide emissions from paddy field as affected by water-saving irrigation. Physics and Chemistry of the Earth, 53, 30, 2012.

21. BUENDIA L.V., NEUE H.U., WASSMANN R., LANTIN R.S., JAVELLANA A.M., ARAH J., WANG
Z., WANFANG L., MAKARIM A.K., CORTON T.M., CHAROENSILP $\mathrm{N}$. An efficient sampling strategy for estimating methane emission from rice field. Chemosphere, 36 (2), 395, 1998

22. ZHENG X.H., WANG M.X., WANG Y.S., SHEN R.X., LI J., HEYER J., KOGGE M., LI L.T., JIN J.S. Comparison of manual and automatic methods for measurement of methane emission from rice paddy fields. Advances in Atmospheric Sciences, 15 (4), 569, 1998.

23. WANG Z.H., LIU X.J., JU X.T., MALHI L.L. Ammonia volatilization loss from surface-broadcast urea: Comparison of vented- and closed-chamber methods and loss in winter wheat-summer maize rotation in North China Plain. Communications in Soil Science and Plant Analysis, 35 (19-20), 2917, 2004.

24. State Environmental Protection Administration of China (SEPAC). Water and wastewater. China Environmental Science Press, Beijing. 2009.

25. LIU L.H., YIN C.B., QIAN X.P. Calculation methods of paddy ecosystem service value and application: a case study of Suzhou City. Progress in Geography, 34 (1), 92, 2015.

26. IPCC. Climate Change 2013: The Physical Science Basis. Contribution of Working Group I to the Fifth Assessment Report of the Intergovernmental Panel on Climate Change Cambridge University Press, Cambridge, United Kingdom and New York, USA. 2013.

27. State Environmental Protection Administration of China (SEPAC). People's Republic of China national report on biodiversity conservation. Chinese Environmental Press, Beijing, China. 1997.

28. TURNER R.K., GEORGIOU S., GREN I.M., WULFF F., SCOTT B., SODERQVIST T., BATEMAN I.J., FOLKE C., LANGAAS S., ZYLICZ T., MALER K.G., MARKOWSKA A. Managing nutrient fluxes and pollution in the Baltic: An interdisciplinary simulation study. Ecological Economics, 30 (2), 333, 1999.

29. YE Y.S., LIANG X.Q., CHEN Y.X., LIU J., GU J.T., GUO R., LI L. Alternate wetting and drying irrigation and controlled-release nitrogen fertilizer in late-season rice. Effects on dry matter accumulation, yield, water and nitrogen use. Field Crops Research, 144, 212, 2013.

30. GOPALAKRISHNAN S., KUMAR R.M., HUMAYUN P., SRINIVAS, V., KUMARI B.R., VIJAYABHARATHI R., SINGH A., SUREKHA K., PADMAVATHI C., SOMASHEKAR N., RAO P.R., LATHA P.C., RAO L.V.S., BABU V.R., VIRAKTAMATH B.C., GOUD V.V., LOGANANDHAN N., GUJJA B., RUPELA O. Assessment of different methods of rice (Oryza sativa. L) cultivation affecting growth parameters, soil chemical, biological, and microbiological properties, water saving, and grain yield in rice-rice system. Paddy and Water Environment, 12 (1), 79. 2014.

31. YU K., PATRICK W.H. Redox window with minimum global warming potential contribution from rice soils. Soil Science Society of America Journal, 68 (6), 2086, 2004.

32. JOHNSON-BEEBOUT S.E., ANGELES O.R., ALBERTO M.C.R., BURESH R.J. Simultaneous minimization of nitrous oxide and methane emission from rice paddy soils is improbable due to redox potential changes with depth in a greenhouse experiment without plants. Geoderma, 149 (1-2), 45, 2009.

33. PEYRON M., BERTORA C., PELISSETTI S., SAIDPULLICINO D., CELI L., MINIOTTI E., ROMANI M., SACCO D. Greenhouse gas emissions as affected by different water management practices in temperate rice 
paddies. Agriculture Ecosystems and Environment, 232, 17, 2016.

34. FANGUEIRO D., BECERRA D., ALBARRAN A., PENA D., SANCHEZ-LLERENA J., RATO-NUNES J.M., LOPEZ-PINEIRO A. Effect of tillage and water management on GHG emissions from Mediterranean rice growing ecosystems. Atmospheric Environment, 150, 303, 2017.

35. ZSCHORNACK T., DA ROSA C.M., PEDROSO G.M., MARCOLIN E., DA SILVA P.R.F., BAYER C. Mitigation of yield-scaled greenhouse gas emissions in subtropical paddy rice under alternative irrigation systems. Nutrient Cycling in Agroecosystems, 105 (1), 61, 2016.

36. HAQUE M.M., KIM G.W., KIM P.J., KIM S.Y. Comparison of net global warming potential between continuous flooding and midseason drainage in monsoon region paddy during rice cropping. Field Crops Research, 193, 133, 2016.

37. KE J., XING X.M., LI G.H., DING Y.F., DOU F.G., WANG S.H., LIU Z.H., TANG S., DING C.Q., CHEN L. Effects of different controlled-release nitrogen fertilisers on ammonia volatilisation, nitrogen use efficiency and yield of blanketseedling machine-transplanted rice. Field Crops Research, 205, 147, 2017.

38. CHEN AQ., LEI BK., HU WL., LU Y., MAO YT., DUAN ZY., SHI ZS. Characteristics of ammonia volatilization on rice grown under different nitrogen application rates and its quantitative predictions in Erhai Lake Watershed, China. Nutrient Cycling in Agroecosystems, 101 (1), 139, 2015.

39. LIU Z.H., LI Z.G., TANG P.Q., LI Z.P., WU W.B., YANG P., YOU L.Z., TANG H.J. Spatial-temporal changes of rice area and production in China during 1980-2010. Acta Geographica Sinica, 68 (5), 680, 2013.

40. National Bureau of Statistics of the People's Republic of China (NBSC). Yearbook of China. Statistics Press, Beijing. 2015.

41. National Development and Reform Commission (NDRC). Outline of China's national plan for medium and long term plan of Food Security (2008-2020), http://www.gov.cn/ jrzg/2008-11/13/content_1148414.htm. 2008. 